\title{
АРХИТЕКТУРА
}

UDC 725.945

\section{A Modernist Memorial for a Classical City: Designs for the Memorial to the Heroic Defenders of Leningrad as Seen by Architects and Audience}

\author{
V.G. Bass \\ European University at Saint Petersburg, \\ 6/1A, Gagarinskaya ul., St. Petersburg, 191187, Russian Federation
}

For citation: Bass, Vadim. "A Modernist Memorial for a Classical City: Designs for the Memorial to the Heroic Defenders of Leningrad as Seen by Architects and Audience". Vestnik of Saint Petersburg University. Arts 11, no. 3 (2021): 555-567. https://doi.org/10.21638/spbu15.2021.310

The article discusses practices of architectural commemoration of the most tragic event in the history of St. Petersburg — Leningrad, the siege. Architects started producing projects for the future memorials in the first months of the unprecedented blockade of the city. During the postwar period some impressive monuments were erected, including one at the Piskarevskoe Memorial Cemetery. There were also dozens of designs submitted to several architectural competitions during the 1950-60s. In the 1960s, Leningrad went through two open architectural competitions for the memorial dedicated to the defenders of the city in the Second World War. The designs were widely publicized, provoking public response going far beyond Soviet standards of freedom of expression in discussing the tragic past. Building on a considerable body of archival materials, the article examines the history of the Monument to the Heroic Defenders of Leningrad and the shaping of its architectural language. Simultaneously, it analyzes some commonalities of "memorial discourse" reflected in feedback texts. The critical responses demonstrate various attitudes towards the contemporary (late modern) architectural characteristic of the majority of competition entries and various visions of its appropriateness for the commemoration of the Siege. Eventually erected in 1975, the monument turned out to be a compromise between the architects' and laymen's visions, between the highly modernist style fashioned by the architects and the expectations of the audience that was skeptical about "Western modernism" and "abstraction" and demanded a narrative memorial with figurative sculpture.

Keywords: Memorial to the Heroic Defenders of Leningrad, Soviet memorials, commemoration of the siege of Leningrad, monument, war memorial, memorial architecture.

The creation of the Memorial to the Heroic Defenders of Leningrad had great significance both for the cultural, political, and architectural history of the city, and for the histo-

(C) St. Petersburg State University, 2021 
ry of the commemoration of the Second World War and the siege of Leningrad ${ }^{1}$. Designed by a team led by architects Sergey Speransky and Valentin Kamensky, and sculptor Mikhail Anikushin, the monument was unveiled in 1975. But the process of design and construction was protracted and complicated, involving several competitions over the course of the 1950s and 1960s; dozens - even hundreds - of designs were produced. The number and variety of participants, decision-makers and stakeholders involved were enormous. Architects, sculptors, artists, design workshops and institutes, creative societies, builders, party and executive authorities (at the city, republic and USSR levels), media, as well as city residents and ordinary Soviet citizens from outside Leningrad all took part.

The memorial was erected at Srednaya Rogatka (from 1962 - Victory Square), near the former city limits, on what was the front line during the war. Thus the monument became a core element of the architectural ensemble marking the entrance to the city from the South, from Moscow.

Why is this subject worth studying? Why is it indicative in terms of both architectural history and the history of Soviet culture?

Firstly, because of the long and complicated design and decision-making process, and the creation of multiple projects that demonstrated diverse and contesting visions not only of the monument itself but also of the memory of the siege and defense of Leningrad.

Secondly, the level of public engagement was unprecedented. City dwellers were asked to express their vision for the monument, to give their opinion on location, program, style and appearance. These proposals were published and discussed in the media alongside entries submitted for two open architectural competitions held in Leningrad in the 1960s. The first competition involved establishing both the memorial site and its architectural solution, while the second was to produce a design for the commemorative complex on Victory Square. The competition designs were presented to a wider audience at exhibitions in 1964 and 1966-1967 respectively, and they provoked a public response that went far beyond Soviet standards of freedom of expression when discussing the tragic past. Today we have a considerable body of visual materials and textual documents (a minimum of some 4.5 thousand pages), including the originals of letters sent to the newspapers' editorial offices, allowing historians to reconstruct how architects and citizens viewed the monument and how the various designs were received.

My research reconstructs the history of the Memorial to the Heroic Defenders of Leningrad, and discusses the designs and corresponding discourse in order to answer the following questions:

- How did professional architects and ordinary people see the memorial: its site, program, composition, architectural language and style?

- How did city dwellers of different ages, occupations, level of education, etc., react to the designs (e. g., those they could see at the exhibitions during the competitions of 1964 and 1966-1967)?

- How did the designs and their public reception correspond to official policies in architecture and the fine arts, to ideological campaigns and current trends in international and Soviet architecture?

- What was the popular vision of the memorial to the defense and siege of Leningrad as reflected in feedback (such as letters to newspapers and exhibition visitor responses)? article.

${ }^{1}$ I would like to express my gratitude to prof. Catherine Phillips for editing and proofreading the 
- What were the commonalities of "memorial discourse" regarding the monument to the heroic defenders of Leningrad? Which characteristic images and events were considered essential to the commemorative narrative?

The main thesis of the article and my research in general may be defined as follows:

Architects and laypeople envisioned the monument in different ways: the former imagined it in abstract modernist forms while the latter tended to favor figurativeness and a sculptural narrative; the built structure was a compromise between these two visions.

The article starts with a discussion of certain problems that complicate the case, then presents an outline of the history of commemoration of the siege and the context in which the competitions were held, while the final part deals with "the memorial discourse" reflected in feedback texts.

\section{Some problems}

To start with, the historian's task is made difficult because of the complicated and multi-level system of Soviet town planning and architectural administration. As a result, one can see diversity, flexibility, vagueness, and slow implementation of memorial projects in cities like Leningrad. Parallel commemorative projects (sometimes on the same or similar topics) were planned for various parts of the city: developed and implemented simultaneously, they were concurrently present in the public consciousness, in media.

For instance, along with the monument on Srednaya Rogatka, work had been ongoing for years on a memorial on Vasilyevsky Island. This monument was just one element of large-scale projects to shape the Leningrad waterfront, reflected in mid-century masterplans for the city. In fact, in documents, designs, and publications of the 1960s to early 1970s it was Vasilyevsky Island that was considered the main place for commemoration of the defense and siege of the city.

On the other hand, commemoration of the siege was a single episode with a broad memorial program, one that presumed the creation of a series of memorials to the Great October Revolution of 1917, to Lenin, to the heroic feats of the Komsomol (Communist Youth), the Young Pioneers, etc. In the postwar decades, therefore, a number of monuments were planned for Leningrad and several competitions were held. Some of these plans resulted in completed structures, some remained on paper - even if contemporaries considered them to be realistic, investing in them considerable time and creativity. All of these plans, both implemented and unrealized, shaped the "body of Leningrad memorials" in the imagination of architects and city dwellers.

Because of this multi-level system of town planning and architectural design, sometimes alternative versions of memorial designs for a particular site were published in various books and magazines at the same period. They also coexisted in architects' minds. Some images were produced by designers of a specific monument, some were just abstract conventional memorial structures included in town-planning projects for a particular district or part of the city, or in the masterplan for Leningrad as a whole. These images were everyday reality for architects, town-planners and inhabitants, published - for instance - in the books and articles of Leningrad's chief architect, Valentin Kamensky, who sought to spread the word about the city's master plan of 1966.

Multiple versions of the memorial at Srednaya Rogatka were developed after the competitions; some of them were presented to the audience in media and at exhibitions. 
The sculptures and their arrangement, the composition of the whole ensemble as well as the solution of the vertical part differed from one version to another, and also from the final structure.

Another problem was the contradictory subject of commemoration, which implied different narratives: the defense of Leningrad and the victory, on the one hand, and the siege on the other. While the former presupposed a conventional heroic and triumphal narrative, of the kind typical of Soviet memorials, the latter could not be realized without the representation of suffering. This ambiguity was extremely clear throughout the history of the memorial. Different versions of the monuments for Srednaya Rogatka or for other places even bore different names in various documents and texts, among them the memorial to the heroic defenders of Leningrad, the memorial to the Victory, "the Victory Monument", or even "the memorial in honor of the heroic defense of Leningrad in 19411943 and the final defeat of German Fascist troops at Leningrad in 1944."

Lastly, we cannot ignore that the Leningrad monument was just one element in a nationwide program of commemoration of the Great Patriotic War and the Victory. Thus the whole project was suffused with ambiguity: with the dualism of the common, Soviet, victory and the local, Leningrad, achievement - the unprecedented siege and the defense of the city.

\section{An outline of the history of commemoration of the siege: the competitions and their context}

Leningrad's architects started designing monuments to the future Victory as early as 1942 , whilst the city was besieged. ${ }^{2}$ Their designs were large-scale, even megalomaniac, commemorative ensembles that were intended to replace structures in the city center destroyed by bombing. Sometimes they looked strange and unorthodox, both traditionalist and paradoxical, the designers sought to stretch the limits of the memorial genre and give expression to their emotions and concerns. The detailed and extensive narrative should be noted, usually represented by sculptural means, that resulted from the architects' endeavor to commemorate history, to capture the trials they faced and the events they witnessed as completely and reliably as possible. The same features characterized the designs of the 1950s-1970s.

The history of the postwar memorials starts with three temporary triumphal arches erected to welcome troops returning home in July 1945 . One of them, designed by Alexander Gegello, was built at Srednaya Rogatka. There were plans to replace these temporary memorials with permanent ones, and Srednaya Rogatka - both the entrance to the city and the actual border of Leningrad during the siege - was the obvious choice. Commemorative designs for this site, and other architectural projects for the southern entrance to Leningrad, were abundant in the 1940s and early 1950s. ${ }^{3}$

2 The commemoration of the siege of Leningrad has been discussed in publications by Yulia Bakhareva, Tamara Kovaleva [1], Lisa Kirschenbaum [2], Steven Maddox [3], wartime memorial designs have been published by Tatiana Malinina $[4 ; 5]$ and also examined by Jean-Louis Cohen [6]. The history of the monument to the heroic defenders of Leningrad and various designs have been discussed in books and articles on Sergey Speransky; there are also several publications dealing with the ensemble of Victory Square and the architectural history of the neighboring area, Moskovsky Prospekt, etc. On the representation of victims and suffering in memorials see e. g., Natasha Goldman's article [7]; Vadim Bass's paper [8] discusses the architectural language of the monuments of the $20^{\text {th }}$ century.

3 See e. g., PhD thesis by Tatiana Prudnikova [9]. 
In 1945, the foundations of the Moskovsky and Primorsky Victory parks were laid, in the southern and northern parts of the city. That same year, a competition was held for commemorative ensembles at the mass graves from the siege period at the Piskarevskoe, Bogoslovskoe, Serafimovskoe, Bolsheokhtinskoe and other cemeteries. There were other competitions for memorial structures in Leningrad in the postwar decade: for instance, in spring 1946 the Leningrad branch of the Union of Soviet Architects held a competition for young designers to create a Victory Arch. But at the turn of the 1940s and 1950s the memory of the siege, Leningrad's unique suffering and feat in withstanding the enemy, were displaced from the mainstream memorial narrative (note, for instance, the transformation and eventual closure of the Museum of the Defense of Leningrad).

A new wave of projects to commemorate the siege and the defense of the city started during Khrushchev Thaw. In 1960, the memorial at Piskarevskoe Cemetery (architect Evgeny Levinson, Alexandr Vasiliev, sc. Vera Isaeva, Robert Taurit et al.) was unveiled, going on to become the main symbolic site that encapsulates the city's grief and immortalizes the victims of the siege, the central embodiment of tragic memory. Subsequent monuments, therefore, could carry a more heroic, life-affirming message.

In June 1956, the Executive Committee of Leningrad Soviet (Council) passed a resolution to launch a competition for a triumphal arch at Srednaya Rogatka to commemorate the victory over the Germans who surrounded Leningrad. But two months previously they had decided to restore the Moscow triumphal gate located not far away, so when the competition was announced in 1957, its subject was altered, and the call went out to design a monument without any specific typological requirements.

The jury claimed that none of the 44 designs submitted fully answered the task. There were no first-class entries, 9 were graded second-rate [I, p.4]. Eventually, the work of Sergey Speransky and his colleagues (Petr Areshev, Vladimir Maslov, Yury Pokrovsky [10, p. 14]) was awarded the $1^{\text {st }}$ prize. Speransky's office had been working for years on planning architectural solutions for the southern part of Moskovsky Prospekt, including the ensemble around the southern entrance to Leningrad.

The culmination of the whole process of design and construction was long in coming. It took two decades from the competition of 1957 to the unveiling of the built structure. The initial intention to open the ensemble for the $20^{\text {th }}$ anniversary of the Victory in 1965 gave way to plans to mark the $50^{\text {th }}$ jubilee of the Great October Revolution of 1917, and finally to mark the $30^{\text {th }}$ anniversary of the end of the war in 1975 . The story's unhurried beginnings, with competitions, discussions, etc., gave way to a last-minute rush to build, which was something typical for Soviet architecture.

The commemoration of the war and the siege of Leningrad was part of official ideological policy, the domain of the party leadership. Surprisingly, the new impetus behind the creation of the memorial in 1960 looks almost like a private initiative. In January 1963 the official jubilee meeting took place to celebrate the $20^{\text {th }}$ anniversary of the break of the siege. During this meeting, the poet Mikhail Dudin proposed the building of a monument using donations from the populace. It was Dudin whom Leningraders considered to be behind the idea to create the memorial: "This meeting was broadcast on TV and many citizens watched it" [II, p. 111]. Dudin's call was published in newspapers, and his words, including "The flame of our memory is eternal", became the official slogans of the campaign.

Was Dudin's idea his personal initiative? Was it directly inspired by the Leningrad Communist Party leadership? Was he merely responding to their unspoken wishes? In the 
absence of any documentary proof, I feel we cannot be sure. On the one hand, we should always keep in mind Dudin's position within Leningrad's creative establishment; on the other, the resolution of the bureau of the City Party Committee "On events relating to the $20^{\text {th }}$ anniversary of the breaking /1943/ of the siege of Leningrad ..." [III, p. 9-10] ordered the holding of that jubilee meeting but made no mention of any monuments.

Certainly, Dudin's suggestion was extremely timely: in 1961 the Central Committee of the Communist Party of the Soviet Union and the Council of Ministers issued the resolution "On the abolition of excesses in spending state and public funds on the building of monuments" and under such circumstances, donations from citizens represented the only way to initiate the making of a large and costly memorial.

The campaign had several dimensions - managerial, propagandist and architectural. A "public committee for assistance in creating the monument" was set up in Leningrad and in 1963 a nation-wide fundraising campaign was launched. In a very short period some 2 million rubles, an enormous amount of money in the mid-1960s, was donated by Leningraders and people from outside the city. Ten years later, in the 1970s, the state had to allot another 10 million to build the monument, since construction costs reached 12 million. The designs were published, shown at exhibitions and discussed at public hearings. Newspapers and media invited people to express their ideas regarding the site, program and design and some of the suggestions and critical responses were published.

In 1964 and 1966-1967 two open competitions were held. The goal of the first was to establish both the best place for the memorial and its underlying "idea", its architectural and sculptural resolution. Since it was seen as preliminary, leaders of the architectural and artistic community of Leningrad were on the jury (according to the standards of competition ethics, those on the jury could not take part in the actual design process).

The organizers emphasized that the competition was intended for the wider public, not just professional architects and sculptors. Designs by amateurs were presented to the public alongside high standard designs submitted by architects, architectural offices and institutes.

Before launching the competition, the Union of Architects produced a summary of approximately a thousand proposals (including 24 sketch designs) from the city's residents, suggesting where the monument should be located. The central part of the city (including Vasilyevsky Island) was the most popular location (mentioned in 350 proposals), while on the periphery of Leningrad 54 votes were given for Kirovsky District, 41 for Pulkovo, 76 for Srednaya Rogatka, 40 for Victory Park and 59 for the city outskirts [IV, p.48]. Architects suggested that the memorial be built on Vasilyevsky Island.

The program of the 1964 competition included the waterfront area of Vasilyevsky Island, the new Lenin Park, Srednaya Rogatka and the Pulkovo area, and participants were also allowed to make proposals for other sites.

A true diversity of vision is reflected in the 83 competition designs (and their reception by the public) and the proposals from residents. Srednaya Rogatka (Victory Square) was by no means the common choice. Some projects for the center of the city enjoyed a positive response, including those involving the demolition of existing structures such as the maternity hospital on Vasilyevsky Island or the late $19^{\text {th }}$ century buildings within the Admiralty shipyard area, and those that proposed the creation of an artificial island in the Neva River, in front of the Stock Exchange building.

The memorial on Victory Square was the subject of a second competition held in 1966-1967. It was seen as the first - feasible - stage of an extensive commemorative 
program, with the main ensemble to be built on Vasilyevsky Island. This program also included "The Green Belt of Glory" or "The Green Belt of Peace", a set of monuments in the Leningrad suburbs on the sites of former battlefields: "The City Public Commission believes that the best way to commemorate the immortal feat of Leningrad would be to create the main monumental and museum ensemble in the North-Western part of Vasilyevsky Island, and initially to build a monument in Moskovsky District (Victory Square Srednaya Rogatka). In the future, another memorial should be erected in Kirovsky district at Lenin Park. All the memorial structures should reflect the common idea: 'For the feat of Leningrad!"'. [11, p. 1]

Sixty entries met the formal program requirements. Stylistically speaking, a number of designs (those submitted by professional architects and offices) represented state-ofthe-art international modernist architecture, employing minimalist metaphor and powerful means of making a psychological impact. There were also figurative and symbolic designs conveying the message through sculpture. There were also several poor or amateur proposals that were straightforward and rather stereotypical.

As architect Aleksandr Macheret wrote in his review, "Those designers who search for an image using sculptural means are able to more successfully solve the problem, since the language of sculpture is more flexible and comprehensible than the more abstract language of architecture" [12, p.6]. One should also keep in mind that "a synthesis of the arts" was the creed of Soviet art theory, critique and practice, so even in the post-Stalinist period, when mainstream architecture was essentially modernist, commemorative designs with sculptural elements were better accepted by juries and the public compared to pure architectural abstractions.

None of the designs were considered to be worthy of the $1^{\text {st }}$ prize. Among projects that received awards, there were those submitted by teams that included Sergey Speransky ( $2^{\text {nd }}$ prize), and Mikhail Anikushin ( $4^{\text {th }}$ prize). These artists, together with Valentin Kamensky, chief architect of Leningrad between 1951 and 1971, were placed at the head of the team entrusted with creating the memorial.

Between the competition and unveiling of the monument, the team produced a number of versions of the design in an attempt to meet the changing requirements of Leningrad party leadership. There were projects that had a 12-meter-tall statue crowning an obelisk, and up to the last moment the design included a small sculpture of a boy symbolizing the future that the defenders of Leningrad had died for. The model for this sculpture was accepted by the committee as late as March 3, 1975, [V, p.70] just two months before the unveiling, which took place on May 9, 1975, while the underground memorial Siege Hall was finished only in 1978.

The very idea to build the memorial at Srednaya Rogatka and the way it was resolved did not earn unanimous public approval. When, for example, the final design was exhibited in the Russian Museum together with two versions of the memorial for Vasilyevsky Island in 1972, the visitors' reaction was far from enthusiastic. ${ }^{4}$

On the one hand, the diversity and vagueness of parallel commemorative plans disoriented both the public and the designers. On the other hand, this flexibility made

4 The majority of the visitors' votes (1529) went to the design by V. Petrov, F. Romanovsky, and sculptor A. Dema (169 votes against). The design by Ig. Fomin, V. Maslov, sculptor L. Lazarev et al. received 489 votes for and 202 against. The design for Victory Square by M. Anikushin, S. Speransky, and V. Kamensky had 218 votes for with 368 against (the total number of the written responses was 2473) [VI, p. 15-6]. 
it possible for the authorities to make rapid changes to their plans according to the development of a particular project and transformations in their vision for the urban layout and construction of a particular district. In 1973, for instance, the designers of the memorial project for Vasilyevsky Island were instructed "to take into account the instructions of Leningrad's Party and Soviet leadership regarding the incorporation into the memorial program of such subjects as: the image of V.I. Lenin; Leningrad as the cradle of the Great October Revolution; and the current achievements of Leningrad, which is striving, along with the whole country, to build Communism" [IV, p. 80]. By that time, the designs for the memorial to the defenders of the city and that to the October Revolution on Vosstaniya Square had been developed independently of each other.

\section{"The memorial discourse"}

Let us turn to the memorial discourse, reflected in letters to newspapers and the public committee and in reviews of the designs exhibited in the House of Architects during the competitions, etc.

The location of the memorial was one of the key points of the discussion. There were two opposing viewpoints.

Those who proposed erecting the monument in the city center provided the following arguments:

— accessibility (for both city dwellers, especially seniors, and tourists);

- the whole city had been under siege, the whole city had fought against the enemy, so there was no point in commemorating one particular site near the frontline the whole area of Leningrad, every and any part of the city was to be considered appropriate for such a memorial;

- the new monument should be just one element in a whole complex of memorial ensembles for Leningrad.

The idea to build the monument on the edge of the city was based on arguments of historical accuracy, which suggested it should be on or near the line of defense. On the other hand, the new city waterfront and seaport planned for Vasilyevsky Island were already planned and construction had begun, and a monument might act as a welcome to visitors arriving in Leningrad. Some letters mention the Statue of Liberty, which the Soviet memorial should, they said, outdo. On the other hand, several exhibition visitors criticized designs for Vasilyevsky Island as kowtowing before Western tourists.

Popular visions of the memorial program included certain common features:

- it should present a detailed and historically correct narrative (battlefields, military units, names of heroes);

- "the names of all those who died in the besieged city;"

- a series of characteristic scenes from Leningrad 1941-1944 (usually in chronological order);

- characteristic images representing various groups of Leningrad citizens and city defenders: conventional (soldiers, sailors, partisans, workers) and non-traditional ("women, children, and old men") [VII, p. 169]. Some letters asserted that images of Leningrad women were essential for a siege memorial: "There is one feature very characteristic of besieged Leningrad that must be reflected in the memorial: 
the feat was one performed above all by women, so it is they who should be represented" [VIII, p. 102]. "Have not the women of Leningrad deserved a monument? Why can a memorial to a woman not adorn the city?" [II, p. 81-2].

I would also underline the audience's extremely high level of emotional engagement. The official invitation to express individual visions of the memorial served as a trigger that launched a whole process of remembering and of breaking the bonds of self-censorship. Sometimes letters included extensive tales of tragic episodes that the author had witnessed, with uncensored details that one could not imagine being published. Along with clichés borrowed from the official discourse, these texts are remarkable for their incredible frankness and the authors' attempt to convey the personal experience of suffering, the memories of an eyewitness, stretching the limits of the siege narrative.

In general, the authors saw their participation in the defense of Leningrad or their experience of living in the besieged city (or their involvement in raising money for the new monument) as giving them the right to express an opinion regarding the future memorial and the designs shown at exhibition.

Alongside professional architects, people without any artistic training or skills, some of them clearly uneducated and almost illiterate, expressed their vision and reviewed the projects. Authors frequently stated that they did not belong to an artistic corporation and possessed no skills in drawing or design. But they felt obliged to express their vision, their opinion. The vocabulary of these reviews naturally reflects the scope of the engagement: designs are often called "offensive", "outrageous", "hideous", "a mockery", "complete filth", "blasphemy", "dreadful squalor that abuses the memory of both the city defenders and those died in the siege" [VII, p.98].

Amateur designers" entries were coldly received: they "would be quite suitable for an exhibition of children's works in a local housing and maintenance office" [VII, p. 150]. According to another exhibition visitor, "what is on display is trash, whether produced by professionals or amateurs; I wonder which is worse" [VII, p. 122].

The public's reception of modernist architectural language seemed quite negative. Designs were said to be "over-full of modernism and concrete" [IX, p. 17]. One should "exorcise completely the spirit of modernism" [IX, p.17]. "Many entries are full of modernistics and cubistics that are completely unnecessary in this instance" [IX, p.58]. "Naked formalism," [VII, p. 98] "A stencil, a homage to Constructivism, naked Constructivism" [VII, p. 170]. "How can abstraction and lifeless symbolism be permitted here?" [VII, p.40]. "One should invest the people's money in a memorial reflecting the Siege, not abstraction" [II, p.34].

Why was modernist architectural language considered inappropriate for a memorial to the defense and siege of Leningrad?

First, the public had no proficiency in interpreting modernist monuments and preferred a conventional sculptural narrative memorial with conventional architectural "signs", elements typical of traditionalist "architecture of memory" (columns, spires, obelisks, etc.). In their letters, these reviewers simply borrowed negative anti-modernist clichés from art criticism and the public discourse of the campaign against abstractionism, "formalist" and non-figurative art (suffice it to mention Khrushchev's famous visit to the Moscow Manege in December, 1962). They were unable to associate "abstract" structures with the memory of the defense and the siege, with their own personal practical and emotional experience or with the historical narrative, whether official or popular: "Some 
designs are difficult to understand for the ordinary people without explanation" [VII, p. 51]. "One needs to be an architect to "find" the idea of the memorial, yet they are supposedly intended for the masses" [IX, p. 17]. "Abstract blocks, pyramids, and parallelepipeds of concrete cannot be a monument to the defenders of Leningrad. Those defenders cannot identify themselves, the ordinary people, with such blocks" [VII, p. 184]. For many city dwellers the projects on display signified only the designers' creative self-expression, authoritarian and arrogant artistic practice. On the other hand, in looking at viewers' responses we should bear in mind unnoticed asymmetry: those who were happy with the designs did not necessarily express their satisfaction, but those who felt insulted were prompted to review the exhibition or write to a newspaper.

Moreover, modernist language was perceived in some letters as a transient fashion, while the memorial was intended to stand through the ages. Lastly, it was thought that a "contemporary" modernist memorial would distort the classical cityscape of Leningrad, which had been saved from destruction in the siege.

The rhetoric of some reviews was essentially anti-Western and nationalist. These authors understood modernist architecture as resulting from foreign, Western, influence: "What modern rubbish! Where is the Russian spirit, where is the art? One can see only spires, steeples, and falling rocks. You look at this monument (to the fame, heroism, and suffering of people in the siege and war) and leave without an impressions, any emotions, and you ask: what on earth is it? The people's donations have been wasted on some kind of abstractionism - on Western rot. We should feel ashamed as Russians. Have we really fallen so low that we cannot produce anything original?" [VII, p. 76] "The spirit of all the designs is very far from Russian architectural traditions. Memorials of this sort could be just as easily put up somewhere in Brasília [the new modernist capital city of Brazil. V. B. ], since they lack any national color" [VII, p.74].

For architects, in turn, modernism was the right choice, the appropriate language. Modernism was the architectural mainstream of the period, the contemporary architecture that they produced and which they admired, and it could be seen on the pages of professional magazines as well as in new city neighborhoods.

The architectural body tried to defend itself by stating that abstraction in architecture was not the same as abstractionism in painting, sculpture, etc. An editorial in the journal Architecture of the USSR in 1964 argued: "In the West, the development of architecture is highly influenced by decadent bourgeois fine art. But the search for new, simple and plain architectural forms should not be associated with abstractionism as it is for some foreign theorists and architects. It is enough to point out the fundamental difference between the geometrical volumes of a pyramid, monument or obelisk and the "sculptural" compositions of contemporary abstractionists, "analogous" in form. They are not the same at all" [13, p.2].

It must also be stressed that the Soviet audience's perception of "the West" was by no means uniform. There was "the evil West" (the USA and other classic capitalist countries), and "the good West", "our West" (usually represented by Cuba, Brazil, etc.), and thus there was "bad" and "good" modernism. One could thus be both a true Soviet architect and a "modernist."

In the commemorative genre, abstract geometric structures, with heavy stone or concrete cubes, pyramids, cantilevers and so on, were considered appropriate above all because of their potential to provoke the viewer's emotions. This language was conventional in inter- 
national commemorative architecture. For example, in 1963 Soviet architects participated in the competition to create a monument at Playa Girón in Cuba. Entries by architects from the USSR (and Leningrad in particular) and the winning design submitted by the Polish team (Marek Budzyński et al.) share the same language and set of formal solutions, visual metaphors and "rhetorical devices." Similar language was characteristic of a number of memorial designs and structures of the 1960s and 1970s, including competition entries for "the Green belt of Glory" (see e. g., "The Broken Ring” by Konstantin Simun and Vladimir Philippov), Soviet war memorials or one to the Armenian genocide (in Yerevan).

\section{Conclusion}

The monument to the Heroic Defenders of Leningrad as built represents the ultimate compromise that brought the protracted, thirty-year-long story, to a close rather than the result of a steady refinement and development of a clear idea. It was a compromise between the visions of architects and audience. It combined fashionable modernist formal language with an abundance of figurative sculpture, satisfying popular demand for an intelligible and customary narrative.

But there was also another dimension to discussions of the commemoration of the siege that was not covered by the monument. A number of letters proposed the construction of utilitarian structures rather than a memorial, from schools and kindergartens, hospitals and youth centers, parks, a zoo and a stadium, to - most importantly - residential blocks to provide housing suitable for those who had defended the city and those inhabitants of the besieged Leningrad who had survived. Such letters often expressed the idea that these people had been ignored or sidelined since the war, that social justice had to be reasserted.

The following example illustrates this point perfectly: "I propose that instead of a monument we build a residential block with comfortable flats (not the small cells they build now). They might be the city's first two or three skyscrapers, depending on resources, but they should be state-of-the-art buildings for the defenders of the city. For those who lived here during the siege and can prove it."

"But what do we see now? We tell the world about the heroic defenders of the city, etc., while they live in cramped flats. And those who spent the war in Tashkent and did not see combat have already settled in Leningrad, while those who spilled their blood go on living as they used to, still waiting for their turn. Let them take those who suffered most in the siege and settle them in these flats. I repeat: the dead need nothing, but Leningrad must pay its dues at last to those who brought the city glory. And when the state is wealthier, that is when to think about a memorial, since by then the defenders of the city will all be in their graves" [VIII, p. 64-5rev].

Thus, the competitions to find a monument to the defenders of Leningrad served as a trigger not only in terms of reshaping the commemorative narrative of the siege, but in bringing out relevant social and political concerns.

To conclude, I would like to quote from a letter that combines some important points of this "memorial discourse," both conventional points and those that challenged the existing tradition of war memorials in the USSR: "When I try to imagine this memorial, I wonder: what kind of monument would those who died defending us like to have? They would probably reject a heavy stone memorial, no matter how magnificent and monumental it might be, how large the sum of money it might cost. 
I believe that the monument should glorify the dead and be joyful and useful to the living. In my mind, there should be two memorials. The first, made of marble, stands at the entrance to Leningrad $\langle\ldots\rangle$, high above the earth and sea. Its inextinguishable light is a beacon for passing ships and can be seen from a distance. It is surrounded with lilac, rose, and jasmine bushes. A number of specific war scenes are depicted on the memorial $\langle\ldots\rangle$. There might be a hunched old woman covering her face in horror as she holds a $<\ldots>$ letter from a soldier; the young daughter is embracing her both crying and comforting her. Perhaps there could be [Soviet war hero] Matrosov huddled up beside a cannon; maybe - a prisoner of war escorted to execution, or a female field medic carrying a wounded soldier from the battlefield. Perhaps the waters of the Baltic Sea, suffused with blood on August, 20, 1941, when German planes and submarines destroyed a convoy of sanitary ships evacuating the hospitals from Tallinn.

One of those who drowned there was my brother, a Baltic Fleet surgeon, who carried on saving others, not himself, right up to the last moment. His aged parents died in Leningrad in the winter of 1941/42, unaware of the loss of their beloved son. For several years his widow waited, hoping desperately for a miracle, the return of her husband. Their child also died.

A lonely old age is the destiny of thousands, dozens of thousands, of women of Leningrad who lost relatives in the war.

But do those who died need imposing gravestones, tons of shiny granite and marble? I know that my brother would have said 'It would be better to use this money to build another hospital or another home for those who can no longer work.' I believe that the same would have been said by many, many others whose fading widows and aged mothers have such need of peace, warmth and comfort.

Let there be a beautiful memorial to those who gave their lives for us, let their feats be immortalized upon it for ages, their heroism and our grief and gratitude recorded. But I see another, and, probably, better memorial next to this one.

It should be a palace in a garden near the marble monument, surrounded with pretty cottages with balconies and terraces. It should be a house of rest and relaxation and of joy for those whom the defenders of Leningrad died for; for those who have been left alone through the loss of relatives in the war; for those who have worked for thirty or forty years and are no longer able to take care of themselves but do not want to be a burden on their relatives.

It should bear not some sad and frightening inscription such as "Hospice", but something like "Recreation sanatorium". It would not have the hospital regulations typical of hospices, rooms housing 15-20 people, dozens of restrictions. The residents would be free and independent. Though they would pay for service and meals, they would have a private room with some precious objects from childhood, family albums, and letters from those who long dead" [II, p. 87-9].

\section{References}

1. Bakhareva, Iuliia, Tamara Kovaleva, et al., authors and comp. Architects of the Besieged Leningrad: Catalogue. St. Petersburg: Gosudarstvennyi muzei istorii Sankt-Peterburga Publ.; NP-Print, 2005. (In Russian)

2. Kirschenbaum, Lisa. The Legacy of the Siege of Leningrad, 1941-1995: Myth, Memories, and Monuments. Cambridge: Cambridge University Press, 2006. https://doi.org/10.1017/CBO9780511511882. 
3. Maddox, Steven. Saving Stalin's Imperial City: Historic Preservation in Leningrad, 1930-1950. Bloomington; Indianapolis: Indiana University Press, 2015.

4. Malinina, Tatiana, comp. Documents and Materials on the History of the Soviet Architecture of 19411945. Chronicle of the War Years. Architectural Press. Executive ed. K. Afanas'ev. Moscow: Nauka Publ., 1978. (In Russian)

5. Malinina, Tatiana. The Theme of Memory in Architecture of the Wartime Period: On the Materials of Competitions and Exhibitions of 1942-1945. Moscow: NII teorii i istorii izobrazitel'nykh iskusstv Publ., 1991. (In Russian)

6. Cohen, Jean-Louis. Architecture in Uniform: Designing and Building for the Second World War. Paris: Editions Hazan, 2011.

7. Goldman, Natasha. "Israeli Holocaust Memorial Strategies at Yad Vashem: From Silence to Recognition". Art Journal 65, no. 2 (2006): 102-22. https://doi.org/10.2307/20068468.

8. Bass, Vadim. "Monument: Who Controls the Past? On one Mechanism of Architectural Commemoration". Sotsiologiia vlasti 29, no. 1 (2017): 122-55. (In Russian)

9. Prudnikova, Tatiana. "The Peculiarity of the Soviet Cultural Policy in Urban Planning (On the Example of Stalin Avenue in Leningrad of the 1940s-50s)". PhD diss., Sankt-Peterburgskii gosudarstvennyi universitet Publ., 2015. (In Russian)

10. “Competitions Results". Arkhitektura i stroitel'stvo Leningrada, no. 1 (1958): 14. (In Russian)

11. Leningradskoe otdelenie soiuza arkhitektorov SSSR. Leningradskoe otdelenie soiuza khudozhnikov RSFSR Upr. kul'tury ispolkoma Lengorsoveta. Design Competition Program for the Monument to the Heroic Defenders of Leningrad in the Great Patriotic War of 1941-1945. $2^{\text {nd }}$ round. Leningrad: tip. Volodarskogo Publ., 1966. (In Russian)

12. Macheret, Aleksandr. "For Your Fear, Leningrad!" Stroitel'stvo i arkhitektura Leningrada, no. 4 (1967): 6-8. (In Russian)

13. "Ideological Goals of Soviet Architecture". Arkhitektura SSSR, no. 6 (1964): 1-2. (In Russian)

\section{Sources}

I. TsGALI SPb. F. 341. Op. 1. D. 477. [Russia. St. Petersburg. Central State Archive of Literature and Art of Saint Petersburg. Stock 341. Inventory 1. File 477]. (In Russian)

II. TsGALI SPb. F.341. Op. 6. D. 2. [Russia. St. Petersburg. Central State Archive of Literature and Art of Saint Petersburg. Stock 341. Inventory 6. File 2]. (In Russian)

III. TsGAIPD SPb. F. 25. Op. 94. D. 36 [Russia. St. Petersburg. Central State Archive of Historical-Political Documentation of Saint Petersburg. Stock 25. Inventory 94. File 36]. (In Russian)

IV. TsGALI SPb. F.341. Op. 1. D. 633. [Russia. St. Petersburg. Central State Archive of Literature and Art of Saint Petersburg. Stock 341. Inventory 1. File 633]. (In Russian)

V. RGALI. F.2458. Op. 8. D. 1490 [Russia. Moscow. Russian State Archive of Literature and Art. Stock 2458. Inventory 8. File 1490]. (In Russian)

VI. TsGALI SPb. F. 105. Op. 2. D. 602. [Russia. St. Petersburg. Central State Archive of Literature and Art of Saint Petersburg. Stock 105. Inventory 2. File 602]. (In Russian)

VII. TsGALI SPb. F.341. Op. 6. D. 30. [Russia. St. Petersburg. Central State Archive of Literature and Art of Saint Petersburg. Stock 341. Inventory 6. File 30]. (In Russian)

VIII. TsGALI SPb. F.341. Op. 6. D. 3. [Russia. St. Petersburg. Central State Archive of Literature and Art of Saint Petersburg. Stock 341. Inventory 6. File 3]. (In Russian)

IX. TsGALI SPb. F.341. Op. 6. D. 31. [Russia. St. Petersburg. Central State Archive of Literature and Art of Saint Petersburg. Stock 341. Inventory 6. File 31]. (In Russian)

Received: March 25, 2021 Accepted: May 27, 2021

Author's information:

Vadim G.Bass — PhD in Art History, Associate Professor; bass@eu.spb.ru 